\title{
DEBUNKING THE POST-RACIAL NOTION: A RACIAL PREJUDICE STUDY IN AMERICAN SOCIETY AS REFLECTED IN ANGIE THOMAS' THE HATE U GIVE
}

\author{
Yusrina Dinar Prihatika \\ e-mail: dinarprihatika@gmail.com \\ Muh Arif Rokhman \\ Universitas Gadjah Mada \\ e-mail: arokhman@ugm.ac.id
}

\begin{abstract}
Today, America is still busy with the problems of inequality, which include racial prejudice.The Hate $U$ Give brings social issues that are rife to people of color, especially African Americans. In her novel, Thomas illustrates the injustice that had happened to the African American community because of the racial profiling that was carried out by white people. The writer uses descriptive analysis method in finding the meaning behind a literary work. The writer also conducts the study using Racial Prejudice theory by McLemore to see the types of prejudice in society. The writer also elaborates it with Du Bois' Double Consciousness in analyzing racial prejudice towards African Americans. The study found out that perceived injustice is still often obtained by African Americans, where they still cannot have their rights as citizens in the United States, such as educational equality, economics, and legal protection. This prejudice is caused by the existence of social class conditions which are constrained by the majority race which tries to maintain its position as a 'ruler' in American society, the other factor is by the spreading Post-Racial ideology where the majority of people think that talking about racial issues is no longer relevant.
\end{abstract}

Keywords: African Americans; racial equality; racial prejudice; postracial; police brutality

\section{INTRODUCTION}

America nowadays is experiencing rapid developments. From a country that has a dark history of slavery to African Americans,
Article information Received: 12 January, 2020 Revised: 26 January, 2020 Accepted: 9 February, 2020 becomes acountry that, for the first time in American history, appointed an African American being the 44th president of the United States. In 2009, a huge history was 
engraved as Barack Obama sat at the highest office in the United States. Obama's victory is not only an achievement for himself, but also for minorities, especially the African American community. American history is quite shaken, seen from how the media responded at that time, which simultaneously reported Obama's victory as a 'historical election' (McCain, 2008). Obama's victory in becoming the president of the United States is a real proof and a new hope for racial minorities who are still experiencing racism. Since Obama's victory, Americans have been faced with a situation where they believe that racism is no longer in America since their president is an African American.

However, racism has not just disappeared since Obama was elected as a president. There are still many cases of racism that have hit America recently. It makes many people from various circles begin to voice out their voices through their work. The Hate $U$ Give is a debuted work by Angie Thomas, which was published in 2017. In her novel, Thomas illustrates that the main character, an African American named Starr, had to witness an injustice that had happened to his friend Khalil Harris due to the racial profiling carried out by white police officers. Thomas narrated her novel through Starr using language and perspective that seemed so personal, remaining the shooting incidents that still awfully happened in America. Her background experiences are able to bring pictures of how African Americans had to stand up against not only the racial prejudice but also the racist society carried out by white people.

This study aims to debunk the Post-Racial notion in the novel. Thus, the question proposed is how racism is represented in the novel and how it manifests through new forms in American society by analyzing its effects towards the characters. After knowing the evidence of racial prejudice in the novel, this study debunked the post-racial notion with a discussion about the situation in present America.

In conducting this study, the writer analyses human relations in American through a literary work. It may include many aspects such as history, sociological background, even culture that exist behind the topic that will be discussed. Thus, the study is conducted under the discipline of American Studies. According to Bruce A. Lohof (1978), American Studies is any discipline focusing on America and its people. There are several issues related to African American aspects.One of the dominant ones is racism,which still exists even until today. Writing a work based on the social phenomenon in society can be said as the form of reflection in public conditions that can be used as a reference in analyzing a particular culture. Meanwhile, in delivering African Americans experiences, the writer will use the Sociological approach. The function of literary work is to see a social situation by considering its social aspects such as institutions, culture, and society, as well as the main function of the social approach. As it explains by Abrams (1976) that a literature might reflect certain social condition or it is an imitation of the universe. It means that behind a work is usually based on the social phenomenon that happened around the writer's surroundings. In analyzing the portrayals of the racism, discrimination, racial prejudice experienced by the characters, the writer use Racism theory.

Racism is a notion where a group of people believe that they have an advantage and assume that the other groups are no better than themselves. This belief tends to be related to 
physical characteristics. Certain standards that they create about how other groups should position themselves in social life are the fundamental point for the beginning of racism. The target of racism is usually a minority group in a society. As Silva said on his book Racism Without Racist: Color-Blind Racism and the Persistence of Racial Inequality in the United States (2006) that racism is not only a notion, and prejudice. It could be something that is systemized. This systemized racism usually called as institutionalized racism which government, and people with power holds major control towards what is happening in America regarding racism issues.

Racial prejudice is expressed in an attitude that shows dislike or distrust (Devine, 1989). This means that certain racial groups are expressing their distrust towards someone or some communities based on fear or even false information. When racial prejudice is done by somebody or group in society, they are not able to give an objective assessment toward the others. Therefore, they will look at everything in a negative way before understanding them closer. Stereotyping plays the big role in this stage where people do not want to get to know each other because of the stereotyping that has been going around in a community. This makes stereotypes as the basis of prejudice and discrimination. The prejudice, which at first only attitudes of negative feelings, gradually turns into discriminatory actions against people who belong to the group that is prejudiced, without any objective reasons on the person subject to those discriminatory actions. McLemore (1983) also explained that in the process of developing a racial prejudice has three factors. The first factor is cultural transmission, where the community will naturally learn something that has been formed in the community itself. The second is the personality trait, which is a form of someone's despair or someone's anger that is bestowed on African Americans, which leads to acts of violence. The last factor is an identity group, where a group has certain preferences in a matter, and then it will be a preference or common standard that will be adopted. Meanwhile, McLemore also explained that the form of discrimination can be seen from three things; situational pressure, group gains, and institutional. Institutional discrimination that occurs in stories is analyzed using McLemore's institutional discrimination because he argues that in fact, institutional discrimination is a form of defense from the superior to maintain their position in society (1983).

As shown in The Hate $U$ Give, prejudice makes the African-American community feel unsafe wherever they are and even though they did nothing wrong. This situation portrays how African Americans live in the society that is socially judging them and trying to adjust with society's mindset. They are trapped or having a double vision; two cultures. Their own culture and the other is the culture they are trying to fit in. The idea and term of double consciousness occur for the first time in 1898 proposed by Du Bois. As an African American, he proposed this theory tominimize the negative images and the representations of African Americans in society. Du Bois also introduced the term that deeply intertwined with the termdouble consciousness, the veil (Bois, 2015). Du Bois believed that the veil has been existed inthe African-American community since they were born. The veil itself, according to DuBois, is the central of double consciousness. Du Bois defined the term double consciousness in The Souls of Black Folk as a sense of always looking at one's self through the eyes of theother, of measuring one's soul by the tape of 
a world looks in amused contemptand pity (Bois, 2015). He also stated in his book,

It is a peculiar sensation, thisdouble consciousness...one ever feels his twoness, an American, a Negro; twosouls, two thoughts, two un-reconciled strivings; two warring ideals in one darkbody, whose dogged strength alone keeps it from being torn asunder (Bois, 2015).

However, the current acts of racism still appear to have similarity, even can be said to be the same as what has happened during the period of slavery and Civil War. White people still see people of colour as a "different" party by separating even though not openly. Like Silva's statement, "Although race, as other social constructions, is unstable, it has a 'changing same' quality at its core" (2006). Silva argues that even though the race category changes over the times, the essence of differences in race categories still the same.

\section{DISCUSSION}

\section{Post-Racial Notion in America}

Before Post-Racial became famous in the Obama era, the term 'Post-Racial' was first coined by an article from The New York Times. In his article published in October 1971, Wooten wrote that at that time Southern America was entering a new era in which technological advances, economics and overall progress would soon replace race relations (Wooten, 1971). This term reappeared and became a big celebration to the American people when Obama won the 44th presidential election in 2008. Many local media stated a reason that America now has entered a new era. Today, the term 'Post-Racial' is used to Obama as the first African American president. Apollon in his study titled Don't Call Them Post-Racial discover that post-racial is a situation where race is no longer a problem in America (2011).

Racism is considered no longer relevant to the social conditions in America where a clear proof has taken place over Obama's victory. It becomes long debates between scholars, politicians, and also activists. The idea about Post-Racial is widespread all over the countries. It is an idea about seeing people as just a human being. It means that they will no longer see their race and physical features. All humans are equal. Silva explained in his book titled Racism Without Racist: Color-Blind Racism and the Persistence of Racial Inequality in the United States (2006) that basically, America is currently living in the ideology of 'Color-Blind Racism' where they believe that equality has been successfully attained, so no more racism, stereotypes or discrimination. Americans no longer see race and colors since they see someone as a pure individual.

\section{Racial Prejudice as Reflected In The Hate $U$ Give}

This study found that racial prejudice happened in Socio-Economic aspects. The ideology of white supremacy led to the separation and rejection of black people from society. This separation has stolen their rights that should have been obtained after the abolition of slavery. It clearly expresses when Maverick talks about 'the chance' that black people still and always fight for due to their struggle to get what is meant to be theirs.

"Why was he a drug dealer? Why are so many people in our neighborhood drug dealers?" I remember what Khalil saidhe got tired of choosing between lights and food.

"They need money," I say. "And they don't have a lot of other ways to get it." 
"Right. Lack of opportunities," Daddy says. "Corporate America don't bring jobs to our communities, and they damn sure ain’t quick to hire us..." (Thomas, 2017)

Thomas portrayed the racial prejudice in the economic sector by showing how Garden Heights deal with the lack of opportunity, and how money plays a vital role in someone's life. White people created a law that disclosed that all humans are equal -but separated, creating two class legal statuses. Segregation occurs, separating blacks from the rest of the community and refusing them. In The Hate $U$ Give, Maverick states that the poor neighborhood of black people is all planned by someone who has power. The lack of opportunities is emphasized on how the government treats African American unfairly. The prejudice that leads into discrimination supported by McLemore's racial prejudice and discrimination theory called group gains (1983) that this situation happens due to the fear of being taking over by the minorities / the newcomers; therefore, instead of providing an equal opportunity, they make discrimination that drives by the racial prejudice.

\section{Low Rates Wages}

Khalil who grew up and enjoyed his teenage years at Garden Heights was a childhood friend of the main character Starr. Growing up in the ghetto is a different thing than growing in another environment. In his book, Thomas describes how the main character lives by likening her neighborhood to a "war zone" (2017). Economic growth holds an important role in the environment itself as it is managed to measure whether a place is a good environment or a bad one. The high needs, the low education and the poor environment in which they live ultimately leads them to bad things. It is clearly what happened in Thomas's novel (2017), where Khalil was forced to become a drug dealer to meet his family needs.

“Two months later, she wasn't pulling her load on the job, 'cause when you're going through chemo, you can't pull big ass garbage bins around. They fired her" (Thomas, 2017).

The way Khalil showed his disappointment and told Starr that his grandma was no longer working at the hospital is another example of how cruel American society was. Khalil also stated that "pull big ass garbage bin", this can be taken as a proof where his African American grandmother used to work as a janitor. It was a work field that indicated a minimum wage. With a low wage, African Americans would struggle to fulfill their needs and linger with poverty. The absence of access to equal job opportunities and fair wages specifically would become their further financial challenges. To close these financial differences and pursue a prominent life, African Americans needed a basic step, such as being wealthy. Wealth, or stable finance, makes it easier for African Americansto investin their future, but it was still a luxury to get as it portrays in Thomas's work.

\section{Racial Prejudice in Education Sector}

With low reading and writing abilities, African Americans who are no longer slaves have to fight in certain situations to survive and find work. These are interrelated and still have an impact today. In the novel, Lisa Carter chose to send her children out of their ghetto school. It proves that their fear of 'failing' is because the system is weighed them down. The government provides job opportunities with fair wages to people with high education. Meanwhile, in fact, in the past good education 
could only be pursued by whites. In 1898, Jim Crow's law separated the facilities, and one of which was separated is the education sector or schools. Schools that mainly were attended by African Americans are usually in remote places with very different facilities from white people's schools. The teachers' quality from the two schools is also very different because most African-American schools are taught by lesstrained teachers with basic education (Education Policy). In terms of education, African-American and Latin-American students throughout the United States tend to be left behind more than white students.

\section{The Prejudice and Imbalances in the Fields of Legal Protection}

Angie Thomas describes how Starr as an African American witnessed an act of injustice committed by someone who should not put any harm on her. Thomas (2017) also stressed about how an African American should behave when they are stopped halfway by the police or police searching. 'The Talk' has become a material taught by African American parents to their children as a form of provision for how they should act if they are confronted in such an urgent situation. African Americans are often being victimizedby the law because its injustice against their right to guarantee the safety of their lives. One of the ten-point programs by the Black Panther that is still being fought for by African Americans is how the law acts on them. In the seventh point of demand, Black Panthers stressed how big the impact of legal protection inequality in America, especially for people with color.McLemore explained in his book that prejudice circulating in the community was a prejudice that was generated due to the cultural transmission where people would naturally have racist thoughts because it was already formed in the community (1983). The stigma or prejudice that had been attached first made Khalil lose his life. Thomas described the brutality committed by the police against Khalil which made Khalil lost his rights when the police conducted a search or traffic stop.

\section{Racial Prejudice in the Aspect of Daily Life}

Everyday racism is a form of mild racism that is carried out in a familiar activity continuously (Essed, 1991). It is often ignored or considered as something that is not so important, but the authors consider that the act of everyday racism has a large impact on the formation of a person's identity and their perspective on a thing. In this case, the media plays an important role in influencing perceptions or shaping public opinions about racism in daily life.

After Khalil allegedly was speeding, and said harshly to the officers, Starr also found that the media was trying to justify Khalil's death by asking for an opinion, which was then disseminated, accepted and remembered by the public audiences. It is clear that Khalil was a victim, but the presumption that was broadcast live on television that most likely saw by most people made the unconfirmed presumption become a fact that is easily deflected, meaning "... a gun was found in the car" (Thomas 2017). Starr, who was still under investigation because she acted as a protected witness, was unable to make any defense of the media's coverage of what actually happened. The media seemed to justify acts of violence committed by police officers, and believed that the death of Khalil was not a doubtful condition.

Hailey, a friend of Starr from Williamson who was a white person, responded to Khalil's case, and she assumed that those police officers were not wrong because he only did his job. 
Based only on information she saw on television, Hailey stereotyped Khalil as a thug and a drug dealer. She even refused to ask for pardon to Starr because she felt everyone had the same thoughts as her about this case. "So you want us to apologize for it even though everybody else did it too?" Hailey asks (Thomas, 2017). McLemore (1983) explained that in the process of racial prejudice, there is what is called a 'group identity' where the preference of a group is made as a standard by racists in prejudicing someone. The portrayal of Khalil by the media was accepted, digested and disseminated with a new form that will usually lead to acts of discrimination.

\section{The Effect of Racial Prejudice towards African American in The Hate $U$ Give}

Racism can happen to anyone, but in this context Reverse Racism committed by minorities is usually a form of self-defense of racist actions that they accept. Racism can also be said to turn around as a form of reaction. African Americans who often get racist acts from whites, in the future will have a certain view that whites are racists, and superior. They can even be at a stage where they feel whites are a threat to their survival. It goes back to the theory in which a person commits an act of social prejudice and generalizes a people. One of theforms of reverse racism that results from racism is how Maverick views almost all white people. Not only the police officer, but Starr hid the fact of having a boyfriend from her dad was also because Maverick hated white people, and Chris was a white person. According to Cashmore (2004) in his book, forms of hostility, racial prejudice, stereotypes about white people committed by minorities are a form of reversed racism.

The next effect is Intra-Racial Prejudice. Prosecution of equal lives for minorities is a long journey. They not only fight racism that comes from white people or the majority, but there are times when racism comes from within the community itself. Black people are shouting out the rights they should get. It would be a different story if an African American went to racially mixed schools, or even made friends with white people. Living in a social environment where white people have full control over the social system that they live in affects the mindset of some African Americans who have narrow thinking.

His peers alienated Sekani in Garden Heights. He has no friends to play with because people in the hood think that Sekani is different from them. It happened only because he went to school with white people. It indicates how intra-racial racism existed in the middle of the community. African Americans, who really want to fight for equality, some of them actually forgot the purpose of equality itself. They were not aware of the racism happening in their communities (Bodenner, 2016). Another example in the Starr case was that the Garden Heights people alienated her because she did not attend a special school for blacks. It was one of the bad things a community could do for its group members by justifying that "you aren't black enough if you're not like us".Therefore, white people's stigma regarding black people will cling to them and turn into anxiety where they will begin to act racial prejudice against each other. It does not stop there, racism makes some African Americans want to 'blend' themselves with the white society so they can escape the bad stigma of African Americans, but it creates new problems among group members.

In the story, Thomas describes the character of Starr of having Double Consciousness, which does not accidentally 
happens. As an African American who lives and blends in a white environment, she suffers from racism and witnesses an impact on her psychological double consciousness. Thomas tells about Starr's difficulties in embracing her identity as an African American. It was first seen at the beginning of the story when Starr for the first time came to a party that was usually held by one neighbor. Starr found that she felt alienated and unable to adjust. "A Garden Heights party and a Williamson party are two very different things." (Thomas 2017) The assumption that Garden Heights and Williamson are the two different worlds constantly mentioned in the novel. According to W.E.B Du Bois (1903), a state of dual consciousness is a state in which a person feels he has two worlds, two thoughts, two behaviors, two things one cannot choose. This situation is experienced by Starr in The Hate $U$ Give. Starr, who is of African American blood, grew up in an African American environment, and made her identity as an African American deeply rooted in her. On the other hand, Starr has another life outside of Garden Heights, the Williamson prep school, where she associates with the majority of white people, and it makes her have to adapt to everything related to white people. Here, Starr's perspective on black people began to change.Starr knew the existence of two worlds in her, and she felt difficult every time she had to change herself from the procedure for a dress and an attitude to speak.

\section{Post Racial Delusion in American Society}

In making of The Hate $U$ Give, Thomas poured her own experience as an African American teenager living in social situations where racial bias and unfair treatment are still common in America today. This novel is a reflection of the condition of America to remind both races that racism is still alive and happens very clearly if people care enough to pay attention to the surrounding environment because racism nowadays happens in plain sight.America claimed to havebeen entering a new era now. A place where minorities hope that equality will exist in every aspect of their life. One of the little prayers is finally granted by Obama's election. The presence of Obama as the first president of the United States of African-American descent was a rapid progress, but slavery and separation of minorities did not completely disappear because the majority government was still controlled by white people. It is very clearly implied in the book Angie Thomas. Racism is only packaged into something new, different and in the smoothest way possible, adapted to the interests of government corporates.

It contrasts to what really happened in America. Racism is still commonly found in various places in various forms. Racism in America today is no longer like racism that occurred in the past when racism is very clearly seen. The existence of post-racial claims, which began to be a hot topic and were celebrated by society, made people's awareness of racism blurred. Racism, which now exists in society, seems to be obscured by the idea of the post-racial itself. White people may have been proud of themselves because Obama's victory was a huge act to break the existence of white supremacy. Meanwhile, African Americans may be prolonged in happiness, so they begin to become unaware of the situation that they face right now. It is dangerous that people who still believe in racism will be considered making a fuss because of their post-racial ideology. Silva explained in his book titled Racism Without Racist: Color-Blind Racism and the Persistence of Racial Inequality in the United States (2006) that basically, America is 
currently living in the ideology of 'Color-Blind Racism' where they believe that equality has been successfully attained, so no more racism, stereotypes or discrimination. Americans no longer see race and colors since they see someone as a pure individual.

Obama's victory is indeed a progress, but it actually proves that his celebrations, which seem to be hailed, are actually bringing an atmosphere of intoxicating to the American state, which is clearly still very backward in terms of racial equality.The post-racial concept that was so exalted after the Obama election seemed to make Obama a mask to cover up racism that was still rooted in America. Discrimination that occurred in the past is still a wedge for African Americans today (Aguirre $\&$ Turner, 2009). Although this form of discrimination is no longer as blatant as what happened in the past, racial discrimination is now secretly happening. It is a way for certain elements in an effort to hide racism that is still very clearly growing and developing in America. In fact, racism is an endemic that always exists in American society.

Stute (2014) explaines that at the moment, $50 \%$ of African Americans are facing racism centered in the economic, school, law enforcement and police force sectors. Institutions that should be responsible for the welfare of the community as fairly as possible are actually utilized by powerful people to pressure minorities, especially to African Americans without letting them know so that they remain in the lower social classes.

After the Segregation Law was abolished, President Nixon proudly declared 'war on drugs' and ordered all Americans to work together in mass incarceration (Duke, 2010). It is intended to make African Americans permanently protected by law, not to have 'freedom' due to their criminal actions. In 2009, data showed that $25 \%$ of African Americans were still living in poverty and this figure is expected to continue to grow if the government calculated by looking at the expenditure figures of African Americans at that time (Aguirre \& Turner, 2009). It can be said that to meet the daily needs of African Americans is still very difficult. It will cause them to live in poverty, and like what the writer has discussed before, poverty has a negative impact on many things. The poverty that still haunts minorities, especially African Americans, occurs due to the failure of the government in seeking an equal opportunity for all people. Valerie Rawlston in VOA Indonesia said that between African-American and white people, there was considerable inequality in the field of equal opportunity; this led to high differences in unemployment rates that came from both sides (Simkins, 2011). Unemployment is an important thing that must put so much attention because unemployment is the measurement of the success or failure of a country's economy.

It is not only employment that causes the minority to be unemployed, but also other inequality that lies in the fact that black people are still under-represented in good jobs with good income. White people have more opportunities to have good employment than minorities, such as African Americans and Latinos (Carnevale, Strohl, Gulish, Werf, \& Campbell, 2019). According to Lesley Williams Reid and Beth A. Rubin, the number of black people employed in good jobs with good salaries is still very low compared to whites (2005). In this case, it can be said that African Americans' situation still does not experience a significant change in the direction better than the period of slavery. Daily expenses that are barely covered by salary keep 
them in a circle of poverty. In 2018, a study showed the median U.S wage around \$ 18.58 per hour, in contrast to the income owned by African Americans who at that time only earned about $\$ 12.41$ to $\$ 13.44$, far from the average income figure (May 2018 National Occupational Employment and Wage Estimates United States, 2018). This data shows a significant difference.

In the educational sector, educators' quality is very important because teachers must have extensive experience to be shared with students. The smarter a teacher is the wider and more experience to be shared with the students. The teacher's experience is another obstacle factor in the field of education. A teacher will not be able to continue to develop their knowledge with inadequate facilities and work environments. Even though former President Obama (Mesecar, 2016) have sought equal and comprehensive educational opportunities in the Every Student Succeeds Act (ESSA) program, itcan be interpreted that equal opportunities in education for African Americans living in segregation areas have not yet been fulfilled. The absence of equal opportunities results in poor educational output. The quality of teachers is also better because according to teachers with high salary and experience will usually be automatically placed in schools that are already advanced, while teachers with low fees and experience are actually placed in high-needs schools (Education Policy) It is an ironic phenomenon where precisely schools with students who are in dire need of educational input, in fact cannot get it because the majority of teachers with high expertise have been placed in urban schools.

Besides the quality of teachers, another thing that has an impact on "insufficient funding" in education is the failure of schools to provide textbooks that can support the quality of student education. Quoting from Tempo (2012) "Most of the schools are attended by minority races in both Latino American and African Americans, only 29\% have calculus classes, while schools with only $40 \%$ choice of physics classes." It is very concerning. The teacher's quality is good, but this also greatly impacts the opportunities for students to learn.

Apart from education and economics, equal legal protection cannot be given by the government to minority groups, especially black people. Racial prejudice, stereotypes, discrimination, and things that refer to the existence of racism or oppression against them are a form of government failure to protect the rights of minorities. The legal enforcement that was supposed to protect them cornered their existence in American society. It is not wrong if black people's response to police officers looks so sensitive because they are people who witness and feel the oppression themselves.

The racism situation most often faced by African Americans and had sparked attention because it created a new movement was the shooting of black people by white police officers. In history, in 1870-1960, more than half of African Americans had been killed by white police officers (Feagin, 2014). It turns out that it does not stop just like that since police brutality continues to this day. They did a lot of mistreatment towards the African American community.

Police brutality does not just happen. As with discrimination in other fields which is a long-term effect of racism in the past, police brutality is also a result of racism that has occurred in the past. The Nixon and Reagan 
governments provided many roles for legal entities to crack down and carry out mass incarceration towards colored people. Drugs are one of the fastest ways to get them behind the bars. Therefore, in his documentary, DuVernay (2016) revealed that the circulation of cracks and powder cocaine was something that Nixon used solely to carry out the political cleansing of African Americans. John Ehrlichman revealed:

The Nixon campaign in 1968, and the Nixon White House after that, had two enemies: the antiwar left and black people. You understand what I'm saying? We knew we couldn't make it illegal to be either against the war or blacks, but by getting the public to associate the hippies with marijuana and blacks with heroin, and then criminalizing both heavily, we could disrupt those communities. We could arrest their leaders, raid their homes, break up their meetings, and vilify them night after night on the evening news. Did we know we were lying about the drugs? Of course we did (Perry, 2018).

Since then, cocaine and drug have often been associated with African and Latino Americans. They continue to carry this until the 21 st century when those who claim America has lived in the post-racial era apparently still see skin color as a barrier to thinking. This related with the statement of Jefferies et al. (2011), that aggressive police factor is most likely due to racial influence.

The police, who should provide security for every citizen, actually become the main factor where minority people do not feel protected. Cassandra Chaney said that the legal enforcement had misconducted the law (Chaney \& Robertson, 2013). Many legal protections in America continuously try to marginalize some groups by several times, sentenced not guilty to police officers who were negligent in carrying out their duties. According to statistical data collected by Nicholas Quah (2015), Of the 15 cases of black shootings by police officers from 20142015, as many as seven cases were not sentenced to police officers who served and were responsible for the incident. The newest case that is still under investigation is the case of police brutality towards George Floyd. Floyd died suffocated from a white police officer.

\section{CONCLUSION}

Prejudices filled with negativities about African Americans shape people's views, and those views are used as a reference in acting on social life. Racial prejudice affects the African American community and all races that live side by side. These acts of discrimination occur in various ways, from small to big things that make African Americans lose their lives. Another impact is that people who unconsciously become targets of racism will automatically have self-defense; it is realized by doing reverse racism. In addition, racial prejudice can also cause disunion within the community that is targets of stereotypes. Living by consuming all the stereotypes thrown at them, will make them blame each other. Besides, the biggest impact of racial prejudice is the formation of a double consciousness that occurs in Starr's character. It formed because there is a limit in her to see everything from both sides.Today, America no longer uses slavery, and Jim Crow's law is considered racist. The fact that the both in the novel and in the real society condition of America today police officers who are abusing their power to conduct such racism can easily escape them from being charged. The society is about to change. African Americans are ready to use their voice to fight racism that happens silently 
and unwittingly around them. Once again, African Americans must again fight for their rights. From this research, the writer wants to convey what Angie Thomas is trying to convey through Starr's character that the spirit to fight for African Americans' rights will continue. America must wake up from its beautiful dream in the name of post-racial.

\section{REFERENCES}

(2009, August 3). National Institute of Justice. Retrieved August 12, 2019, from https://nij.ojp.gov/topics/articles/useforce-continuum

(2015). The Role of Racial Profiling in Encounters with Law Enforcement. Social Justice Brief , 3-4.

Abrams, H. M. (1976). The Mirror and The Lamp: Romantic Theory and the Critical Tradtion. London: Oxford University Press.

Abrams, M. A. (1988). Social Identification: A social psychology of itergroup relations and group processes. Florence, KY, US: Routledge.

Aguirre, A. J., \& Turner, J. H. (2009). American Ethnicity : The Dynamics and Consequences of Discrimination. New York: McGraw-Hill Companies, Inc.

Apollon, D. (2011). Don't Call Them "PostRacial". Millenials' Attitudes On Race, Racism and Key Systems in Our Society. Applied Research Center.

Austin, A. (2013, July 22). African Americans are still concentrated in neighborhoods with high poverty and still lack full access to decent housing. Retrieved November 20, 2019, from https://www.epi.org/publication/africanamericans-concentrated-neighborhoods/
Barack Obama, Warga AS Keturunan Afrika Pertama Terpilih Sebagai Presiden. (2008, November 5). Retrieved January 7, 2020, from https://www.voaindonesia.com/a/a-322008-11-05-voa1-85112332/8987.html

Berman, M. (2008). All Power To The People: The Black Panther Party As The Vanguard of The Opressed. Florida: Florida Atlantic Unversity.

Bodenner, C. (2016, July 22). The Atlantic : Stories of Intraracial Prejudice. Retrieved December 12, 2019

Bois, W. D. (2015). The Souls of Black Folk. New York: First Yale University.

Brennan, F. (2017). Race Rights Reparations: Institutional Racism ad the Law. New York: Routledge.

Brownie, J. (2007). Rooted in Slavery: Prison Labor Exploitation. Spring.

Bryson, S. (1998). Relationship Between Race and Attitudes Towards Black Men. Journal of Multicultural Counseling and Development , 282-294.

Carnevale, A. P., Strohl, J., Gulish, A., Werf, M. V., \& Campbell, K. P. (2019). The Unequal Race for Good Job : How Whites Made Outsize Gains in Education and Good Jobs Compared To Balcks and Latinos. Washington DC: JPMorgan Chase \& CO.

Cartaya, M., Watts, A., \& Levenson, E. (2019, October 14). Former Police Officer Found Not Guilty of Murder in Shooting Death of Unarmed Black Veteran. Retrieved January 14, 2020, from https://edition.cnn.com/2019/10/14/us/ant hony-hill-robert-olsen-trial-notguilty/index.html 
Cashmore, E. (2004). Encyclopedia of Race and Ethnic Studiies. Routledge.

Cassandra Chaney \& Robertson, R. (2013). "Racism and Police Brutality in America" New York: Springer Science,. Springer Science .

Chaney, C., \& Robertson, R. V. (2013). Racism and Police Brutality in America. Springer Science and Business Media, 495.

Christanti, Y. (2019). Double Consciousness in Starr Carter in Angie Thomas' Novel The Hate $U$ Give. Surabaya: Perpustakaan Universitas Airlangga.

Clark, A. D., Danztler, P. A., \& Nickels, A. A. (2018). Black Lives Matter: (Re)Framing the Next Wave of Black Liberation. Researchgate, 146.

Creswell, J. W. (2013). Research Design. Qualitative, Quantitative, and Mixed Methods Approaches. California: Sage Publication, Inc.

Demby, G. (2013, May 22). Code Switched : Race and Identity Remixed. Retrieved December 9, 2019, from https://www.npr.org/sections/codeswitch/ 2013/05/22/186087397/where-did-thatfried-chicken-stereotype-come-from

Devine, P. G. (1989). Stereotypes and prejudice: their automatic and controlled components. Journal of Personality and Social Psychology.

Drug Enforcement Administration. (2013). Cocaine. Office of Diversion Control.

Dubois, W. E. (1903). The Souls of Balck Folk. New York: First Yale University.

Duke, S. B. (2010). Mass Imprisonment, Crime Rates, and the Drug War: A pEnological and Humanitarian Disgrace. Yale Law School Legal Scholarship Repository, 1.

DuVernay, A. (Director). (2016). 13th [Motion Picture].

Ed Trust. (2003, January 1). African American Achievement in America. Retrieved 16 , 2020, from https://edtrust.org/resource/africanamerican-achievement-in-america/

Education Policy. (n.d.). Retrieved January 6, 2020, from New America: https://www.newamerica.org/educationpolicy/topics/school-funding-andresources/school-funding/fundingdisparities/

Essed, P. (2002). Everyday Racism. In D. T. Solomon., A companion to Racial and Ethnic Studies, 202-16. Malden: Blackwell.

Essed, P. (1991). Understanding Everyday Racism: An Interdisciplinary Theory. Newbury Park: Sage.

Feagin, J. R. (2014). Racist America; Roots, Current Realities, and Future Reparations. New York: Routledge Taylor \& Francis Group.

Fredrickson, G. M. (1981). White Supremacy ; A Comparative Study In American And South African History. New Yoek: Oxford University Press.

Gibson, A. (1980). The American Indian: Prehistory to the present. Lexington: Globe Arizona History.

Gordon, T. (2016). Racial Profiling and Moral Responsibility for Racialized Crime. . Hamilton: Mcmaster University. .

Gordon, T. (2016). Racial Profiling and Moral Responsibility for Racialized Crime. 
Master Thesis, Hamilton: Mcmaster University.

Government Publishing Office. (1992). Slavery And Involuntary Servitude. . GPO.

Hafner, J. (2018). Police killings of black men in the U.S. and what happened to the officers. USA TODAY.

Haney J. Timothy, K. B. (2011). "Reconciling Academic Objectivity and Subjective Trauma:The Double Consciousness of Sociologists who Experienced Hurricane Katrina. Sage Journal , 101.

Hannerz, U. (1969). Soulside : Inquiries into Ghetto Culture and Community. New York: Columbia University Press.

Hickman, D. E. (2002). Racial Profiling: A Survey of African American Police officers. Police Quarterly.

Huckabee, T. (2016, July 16). The Problem with Saying 'All Lives Matter'. Retrieved January 23, 2020, from https://relevantmagazine.com/current/nati on/problem-saying-all-lives-matter

Hutami, W. (2014). Racial Prejudice Revealed in Harper Lee's To Kill A Mocking Bird. Undergraduate Thesis, Universitas Negri Yogyakarta.

Jefferis, E., Butcher, B., \& Hanely, D. (2011). Measuring perceptions of police use of force. Police Practice and Research , 81.

Kulaszewicz, K. E. (2015). Racism and the Media: A Textual Analysis. Master of Social WOork Clinical Research Paper, 10.

Labor Force Characteristics by Race and Ethnicity. (2018, August). Retrieved January 13, 2020, from U.S Bureau of Labor

Statistics: https://www.bls.gov/opub/reports/raceand-ethnicity/2017/home.htm

Lawrence, K., \& Keleher, T. (2004). Chronic Disparity: Strong and Pervasive Evidence of Racial Inequalities, Poverty Outcomes. Race and Public Policy Journal Article, 5.

Leigh, D. (2015, August 12). The Guardian. Retrieved December 6, 2019, from https://www.theguardian.com/commentis free/2015/aug/12/media-misrepresentsblack-men-effects-felt-real-world

Lewis, L. (2008). African American Vernacular English. Maryland: University of Maryland.

Lippman, W. (1922). Public Opinion. United States: Harcourt.

Lockett, T. N. (2013). EFFECTS OF RACISM AND DISCRIMINATION ON PERSONALITY DEVELOPMENT AMONG AFRICAN AMERICAN MALE REPEAT OFFENDERS. Master Degree, California State Polytechnic University.

Lohof, B. (1978). Through the Eyes of the World: International Essay in American Studies. Delphi: The Macmillan Company of Indian Ltd.

Lopez, G. (2016, August 8). Black parents describe "The Talk" they give to their children about police. Retrieved December 9, 2019

Lopez, I. F. (2011). IS THE "POST" IN POSTRACIAL THE "BLIND" IN COLOR BLIND? Cardozo Law Review, 809.

May 2018 National Occupational Employment and Wage Estimates United States. (2018, May). Retrieved January 13, 2020, from U.S Bureau Labor Statistics: https://www.bls.gov/oes/current/oes_nat. htm 
McCain, J. (2008, November 5). McCain's Consession Speech. Retrieved January 7, 2020, from https://www.nytimes.com/2008/11/04/us/ politics/04text-

mccain.html?mtrref=www.google.com\& gwh=E43795FA67008C2235AF0225DC EEEEC4\&gwt=pay\&assetType $=$ REGIW ALL

McLemore, S. D. (1983). Racial and Ethnic Relations in America . Massachusetts: Allyn \& Bacon ltd.

McLemore, S. D. (1983). Racial and Ethnic Relations in America. Massachusetts: Allyn and Bacon, Inc.

McLemore, S. D. (1983). Racial and Ethnic Relations in America: Second Edition. Massachusetts: Allyn and Bacon, Inc.

Menifield, C. E., Shin, G., \& Storther, L. (2019). Do White Law Enforcement Officers Target Minority Suspects? The American Society for Public Administration, 56.

Mesecar, D. (2016). Briefing: Public Education Funding Inequity in an Era of Increasing Concentration of Poverty and Resegregation. U.S. Commission on Civil Rights, 4. Washington, D.C: Lexington Institute.

Myrdal, G. (1940). An American Dilemma. New York: Routledge.

Nogueira, S. G. (2013). Ideology of white racial supremacy: colonization and decolonization processes. Psicologia \& Sociedade , 23-32.

North Carolina. (1831). North Carolina Digital Collections. Retrieved October 17, 2019, from digital.ncdcr.gov: http://digital.ncdcr.gov/cdm/ref/collection /p249901coll22/id/175790
Nurcahyani, E. (2007). The negative impacts of racial prejudice and discrimination upon the life of black American society in the Northern Cities as reflected in Richard Wright's Native Son. Undergraduate Thesis, Universitas Sebelas Maret.

Obama, B. (Performer). (2008, March 18). A More Perfect Union. Speech presented at the constituion center, Philadelphia.

Perry, M. J. (2018, June 14). The shocking story behind Richard Nixon's 'War on Drugs' that targeted blacks and anti-war activists. Retrieved January 13, 2020, from https://www.aei.org/carpe-diem/theshocking-and-sickening-story-behindnixons-war-on-drugs-that-targetedblacks-and-anti-war-activists/

Political Participation Group. (2009). "POSTRACIAL" AMERICA? NOT YET: WHY THE FIGHTS FOR VOTING RIGHTS CONTINUES AFTER THE ELECTION OF PRESIDENT BARACK OBAMA. New York: NAACP Legal Defense and Educational Fun, Inc.

Quah, N. (2015, May 1). Here's A Timeline Of Unarmed Black People Killed By Police Over Past Year. Retrieved January 13, 2020, from https://www.buzzfeednews.com/article/ni cholasquah/heres-a-timeline-of-unarmedblack-men-killed-by-police-over

Ratna, N. K. (2006). Teori, Metode, dan Teknik Penelitian Sastra. Yogyakarta: Pustaka Pelajar.

Ratna, N. K. (2003). Paradigma Sosioogi Sastra. Denpasar: Pustaka Pelajar.

Reid, L. W., \& Rubin, B. A. (2005). "Integrating Economic Dualism and Labor Market Segmentation: The Effects of Race, Gender, and Structural Location 
on Earnings, 1974-2000. The Sociological Quarterly, 405-432.

Richard Delgado, J. S. (2001). Critical Race Theory : An Introduction. New York: New York University Press.

Rif'ah, I. (2008). Stereotyping blacks in Richard Wright's Native Son. Thesis Master, Universitas Gadjah Mada.

Ritchie, A., \& Mogul, J. (2008). In the Shadows of the War on Terror: Persistent Police Brutality and Abuse of People of Color in the United States. DePaul Journal for Social Justice , 180.

Rowe, C. J. (2000). Post-Nationalist American Studies. Berkeley and California: University of California Press, Ltd.

Schaefer, R. T. (2008). Encyclopedia of Race, Ethnicity, and Society. California: SAGE Publications, Inc.

Schorr, D. (2008, January 28). A New, 'PostRacial' Political Era in America. Retrieved January 23, 2020, from https://www.npr.org/templates/story/story .php?storyId=18489466

Silva, E. B. (2006). Racism Without Racist: Color-Blind Racism and the Persistence of Racial Inequality in the United States. Maryland: Rowman \& Littlefield Publishers ltd.

Silva, E. B. (2006). Racism Without Racist: Color-Blind Racism and the Persistence of Racial Inequality in the United States. Maryland: Rowman \& Littlefield Publishers ltd.

Simkins, C. (2011, April 10). Kehidupan Banyak Warga Kulit Hitam AS Masih Memprihatinkan. Retrieved January 12, 2020, from https://www.voaindonesia.com/a/kehidup an-banyak-warga-kulit-hitam-asmemprihatinkan-119561604/91919.html

Stannard, D. (1992). American holocaust: The conquest of the new world. New York: Oxford University Press.

Stokely Carmichael, C. V. (1967). The Politics of Liberation in America. New York: Random House.

Stute, D. (2014, November 27). Diskriminasi Kulit Hitam di Amerika Serikat. Retrieved January 8, 2020, from dw.com: https://www.dw.com/id/diskriminasikulit-hitam-di-amerika-serikat/g18091393

Sullivan, S. (2003). Blackwell Guide to American Philosophy. Blackwell Publishing.

Taneja, V. (2012). Socio-Philosophical Approach to Education. New Delhi: Atlantic Publishers \& Distributor. Pvt. Ltd.

Taylor, M. F. (1994). Theories of Intergroup relations: Interntional social psychologycal perspectives. Second Edition. New York: Praeger.

Tempo.co. (2012, March 6). Sekolah di AS Bersikap Rasis. Retrieved January 6, 2020, from Tempo.co: https://dunia.tempo.co/read/388420/sekol ah-di-as-bersikap-rasis

The Use-of-Force Continuum. (2009, August 3). Retrieved January 13, 2020, from https://nij.ojp.gov/topics/articles/useforce-continuum

Thomas, A. (2017). The Hate U Give. London: Walker Books.

Tom LoBianco . (2016). Report: Aide says Nixon's war on drugs targeted blacks, hippies. CNN Politics. 
Tyson, L. (2006). Critical Theory Today. New York: Routledge.

US Departmentof Health and Human Services. (2019, August 22). Retrieved January 13, 2020 , from https://www.minorityhealth.hhs.gov/omh/ browse. $\operatorname{aspx}$ ?lvl=3\&lvlid=61

Vernon, J. (2017, April 18). The Black Panthers' 10-Point Program. Retrieved January 13, 2020, from http://blackpower.web.unc.edu/2017/04/t he-black-panthers-10-point-program/

Wacquant, L. (2004). Ghetto. International Encyclopedia of the Social \& Behavioral Sciences, 3.

Wacquant, L. (2004). Ghetto. . International Encyclopedia of the Social \& Behavioral Sciences., 3.

Walker, A. (2011). Racial profiling separate and unequal keeping the minorities in line-the role of law enforcement in America. . St. Thomas Law Review vol. $23,576-619$.

Wark, C. (2007). Emory Bogardus and the Origins of the Social Distance Scale. The American Sociologist , 390-391.

Wellman, M. (2017, March 7). Report : The Race Gap in Higher Education is Very Real. Retrieved January 6, 2020, from https://www.usatoday.com/story/college/ 2017/03/07/report-the-race-gap-inhigher-education-is-very-real/37428635/

Wooten, J. T. (1971, October 5). Compact Set Up for 'Post-Racial' South". Retrieved January 23, 2020, from https://timesmachine.nytimes.com/times machine/1971/10/05/79156105.html?pdf _redirect $=$ true $\&$ site $=$ false

Yanti, N. R. (2019). Starr Carter's Brave Decisions against Institutional Racismin Angie Thomas' The Hate U Give. Surabaya: English Department, UIN Sunan Ampel Surabaya.

Young, V. A. (2011). From Bourgeois to Boojie: Black Middle Class Perfomances. Wayne: Wayne State University Press.

Yunitri, N. W. (2019). Racism in The Novel The Hate U Give by Angie Thomas. Bali: Jurnal Humanis, Fakultas Ilmu Budaya Unud.

Wooten, J. T. (1971, October 5). Compact Set Up for 'Post-Racial' South". Retrieved January 23, 2020, from https://timesmachine.nytimes.com/times machine/1971/10/05/79156105.html?pdf _redirect $=$ true $\&$ site $=$ false 